\title{
Appendix /
}

\section{Carbon Transport in the Bottom Boundary Layer

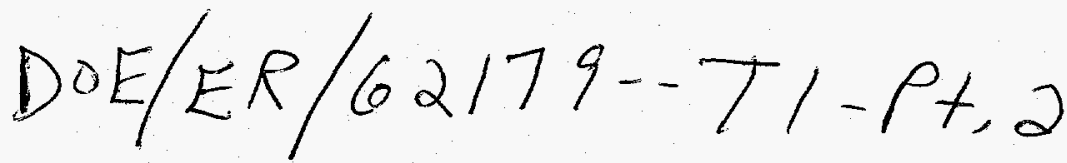

FINAL REPORT

\author{
Ian D. Walsh \\ Department of Oceanography (409) 845-7521 \\ Texas A\&M University \\ College Station, Texas 77840 \\ Walsh@ocean.tamu.edu
}

\section{Introduction}

The central goal of DOE' Ocean Margin Program (OMP) has been to determine whether continental shelves are quantitatively significant in removing carbon dioxide from the atmosphere and isolating it via burial in sediments or exporting it to the open ocean (Program Announcement; 1991). The purpose of this subcontract was to recover and process samples from two sediment traps deployed on the continental slope in conjunction with the OMP physical oceanography mooring program.

\section{Results and Discussion}

Two OSU Tracer-15 multicup sediment traps were deployed on the physical oceanography mooring 27 in February, 1996. This mooring was deployed at a water depth of $1000 \mathrm{~m}$. The mid-water trap was at a depth of $496 \mathrm{~m}$ (504 meters above bottom). The deep trap was at a depth of $832 \mathrm{~m}$ (168 meters above bottom). The mooring was recovered in May 1996. Samples were collected from 2/13/96 to 5/8/96. Both sediment traps were recovered and were found to have followed their programmed high resolution (6 day interval) sampling sequence. However, even with the very short sampling period, the trap within the benthic boundary layer appeared to have clogged during or following the first three sample periods. The first tr ree cups from this trap were almost completely filled with material. Subsequent cups had cnly a small amount of fresh material. The mid-water trap did not suffer this fate, though large amounts of material were recorded within a highly variable sequence of samples. 


\section{DISCLAIMER}

This report was prepared as an account of work sponsored by an agency of the United States Government. I Heither the United States Government nor any agency thereof, nor any of their employees, makes any warranty, express or implied, or assumes any legal liability or responsibility for the accuracy, completeness, or usefulness of any information, apparatus, product, or process disclosed, or represents that its use would not infringe privately owned rights. Reference herein to any specific commercial product, pricess, or service by trade name, trademark, manufacturer, or atherwise does not necessarily constitute or imply its endorsement, recommendation, or favoring by the United States Government or any agency thereof. The views and opinions of authors expressed herein do not necessarily state or reflect those of the United States Government or any agency thereof. 


\section{DISCLAIMER}

Portions of this document may be illegible electronic image products. Images are produced from the best available original document. 
The measured trap bulk flux from the mid-water trap for this time period averaged $12.9 \mathrm{~g} \mathrm{~m}^{-2} \mathrm{~d}^{-1}$ and ranged from 2.2 to $29.3 \mathrm{~g} \mathrm{~m}^{-2} \mathrm{~d}^{-1}$. These are among the highest fluxes ever reported for similarly situated sediment traps (i.e. off the shelf and out of a benthic boundary layer). In contrast, buik fluxes measured on the slope in the Gulf of Mexico in a water depth of $1500 \mathrm{~m}$ ranged from 0.15 to $0.35 \mathrm{~g} \mathrm{~m}^{-2} \mathrm{~d}^{-1}$, with the highest fluxes recorded in the near-bottom sediment traps. The SEEP-II program deployed sediment traps on moorings in a water depth of $1000 \mathrm{~m}$ on two mooring transects to the north of the OMP mooring array (Biscaye and Anderson, 1994). Over the deployment period (1988 through April 1989) the similarly situated traps (mid-water on the $1000 \mathrm{~m}$ mooring) recorded time weighted means of 0.30 and $0.46 \mathrm{~g} \mathrm{~m}^{-2} \mathrm{~d}^{-1}$ (Biscaye and Anderson, 1994). The midwater trap on the southern line's highest recorded flux was $2 \mathrm{~g} \mathrm{~m}^{-2} \mathrm{~d}^{-1}$ in February 1989 . The SEEP-II program did recort very high bulk fluxes at shallower stations, ranging from 10.4 to $22.5 \mathrm{~g} \mathrm{~m}^{-2} \mathrm{~d}^{-1}$ from February through March of 1989.

All processing of the sc.mples from the mid-water trap has been completed, and sub-samples have been split and distributed to other investigators and laboratories for further analysis.

\section{Mooring 27 Shallow Trap Flux}

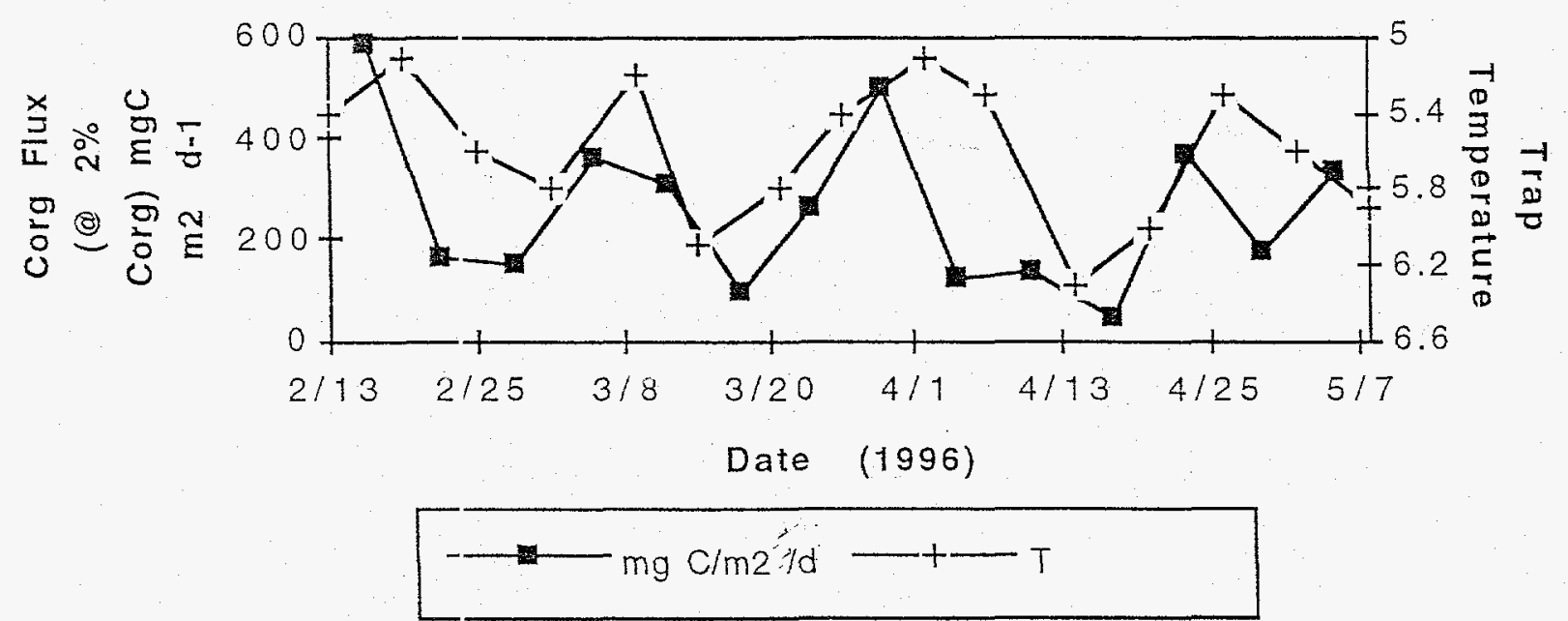

The OSU Tracer 15 sedinent traps are equipped with a thermister which is read at each 'event' i.e. sample cup rotation. The figure above plots the bulk $\mathrm{C}_{\text {org }}$ flux (assuming a conservative $2 \%$ Corg fraction of the bulk flux) time series from the mid-water column 
trap with an overlay of the temperature recorded by the thermister. Note that the trap temperature scale is inverted. There is exceptional coherence between the flux record and the temperature record. An early supposition was that the position of the Gulf Stream wall relative to the slope off Cape Hatteras could control the amount and/or directional fate of the presumed export of material from the shelf. Since the isotherms under the Gulf Stream are depressed relative to the Mid-Atlantic Bight waters, an increase in the temperature at the trap indicates are greater influence of the Gulf Stream at that site. Thus the coherence in the temperature and flux signals suggests that as the Gulf Stream wall moves towards Cape Hatteras the flux at the site decreases.

At least two papers incorporating these results with the results of the physical oceanographic mooring program are planned. No unobligated funds are anticipated to remain at the end of the project.

\section{REFERENCES CITED}

Biscaye, P.E. and R.F. Anderson, 1994. Fluxes of particulate matter on the slope of the southern Middle Atlantic Bight: SEEP-II. Deep-Sea Res. II, V 41, 459-510.

Walsh, I.D. and W.D. Gardner, 1992. Comparison of large particle camera profiles with sediment trap fluxes. Deep-Sea Research 39, 1817-1834. 